\title{
TYPOLOGY OF THE FOURTH GENERATION OF HUMAN RIGHTS
}

Serhii M. Perepolkin Department of International Law, Educational Scientific Institute of Law and International Legal Relations, University of Customs and Finance 2/4 Vladimir Vernadsky Str., Dnipro, Ukraine, 49000 https://orcid.org/0000-0003-2914-5898 psm-13@ukr.net

Danylo S. Perepolkin Student of Faculty of Law of V.N. Karazin Krarkiv National University 4 Svobody Sq., Kharkiv, Ukraine, 61022 https://orcid.org/0000-0001-5821-1810 danil6875@gmail.com

Milena V. Averianova Student of International Law Faculty of Yaroslav Mudryi National Law University 4 Dynamivska Str., Kharkiv, Ukraine, 61023 https://orcid.org/0000-0001-5131-2934 averyanova.milena@icloud.com

\footnotetext{
Abstract. The article examines the approaches of foreign and Ukrainian scientists to the division of human rights into three generations and the adoption of the category «fourth generation of human rights» into the scientific turnover. It has been established that both the initiative to put the said proposal into practice and the legislative consolidation of human rights defined as belonging to the fourth generation of human rights at national and international levels are ambiguously perceived by representatives of different nations. It is emphasized that human rights are a complex of natural and indestructible freedoms and legal possibilities, which have emerged due to the fact of human existence in society. Jurisprudence acknowledges the existence of three generations of human rights, each of which had arisen from the need to meet needs that arose alongside the course of human evolution. Nowadays, we can say that a radically new generation of human rights is emerging. Its appearance is related to the technological progress of humanity. The rights of the fourth generation are a category of rights that is ambiguously perceived by society in different countries. A large number of such rights is criticized both by religion and by morality. At the same time, notwithstanding the ongoing scientific debate on the formation of the fourth generation of human rights, it is necessary to acknowledge the existence of human rights, which include the right to die, the human right to dispose of the organs and
} 
tissues of his body, sexual rights, reproductive rights, the right to change sex, digital rights. The fourth generation of human rights is in its formation, and therefore the scientists' proposed approaches to the classification of human rights based on exhaustive lists cannot fully reflect its actual state. In our opinion, at the present stage of its formation, the catalog of human rights of the fourth generation should include digital rights and somatic rights. It is important to emphasize that the doctrinal discussion of the fourth generation of human rights will not provide a complete overview of the topic. Therefore, there is a need to conduct a comprehensive analysis of specific human rights of the fourth generation at the international level, taking into account the consequences that their introduction or refusal to be recognized and implemented may result.

Keywords: Human Rights, the generation of human rights, digital rights, somatic rights.

\section{INTRODUCTION}

Despite the active scientific discussion during the XX century and at the beginning of the XXI century, a topic of human rights issues continues to attract the attention of representatives of the legal doctrine of different nationalities. The subjects of their research incorporate both theoretical and practical aspects of human rights. The prior includes the classification of human rights, in particular, their division into several generations. An analysis of recent research and publications in this area suggests that scholars generally acknowledge the actuality of three generations of human rights, characterizing them as follows.

The first generation of human rights (XVII - XVIII centuries) lays down the foundation of individual liberty. Its formation has been precipitated by the need to, firstly, protect people from state arbitrariness and, secondly, to guarantee the legal equality of people under the law and before the court. The list of primary rights of the first generation includes the right to life, the right to liberty, the right to private property, and others. Their legal framework was summed up by the adoption of the International Covenant on Civil and Political Rights of December 16, 1966. (International Covenant..., 1966a)

The second generation of human rights (first half of the XX century) is an assemblage of social, economic, cultural rights. All of them have developed during the fight against social inequality as a result of the advancement of the universal standard of living. Examples of the fundamental rights of the second generation are the right to work (with concomitant warranties such as performing under equitable conditions and receiving equal pay for equal work), the right to use cultural heritage, the right to have an adequate standard of living, etc. Their legal support was also achieved through the adoption of a codified international act the International Covenant on Economic, Social and Cultural Rights of December 16, 1966. (International Covenant..., 1966b).

The third generation of human rights (second half of the XX century) is a set of socalled collective rights, namely the rights of nationalities, nations, as well as the rights of vulnerable groups (women, refugees, children). The formation of this generation of rights is associated with the emergence of national liberation movements and with the worsening of 
global problems, notably in the second half of the twentieth century after the Second World War. The list of fundamental rights of the third generation includes the nation's right to self-determination, the right to peace (Declaration of the United..., 1972; Declaration on the Right..., 1986; Rio Declaration..., 1992).

Some scholars, the number of which increases every year, insist that a new type of rights has emerged between the XX and XXI centuries. Therefore, they believe that such human rights are to be included in the new generation of human rights. Scientists mostly attribute the appearance of the fourth generation of rights to the development of technical progress of society, in particular biology, genetics, medicine, chemistry, IT. At the same time, it is noteworthy that the representatives of the legal doctrine have not yet managed to reach a consensus on which human rights to include in the fourth generation and which of the said rights have derived from the rights of previous generations.

In light of the foregoing, the purpose of the article is to analyze the approaches to the phenomenon of the fourth generation of human rights and to discuss the authors vision of their typology.

\section{MATERIALS AND METHODS}

Various methods of scientific research were used to achieve the objective of the article, specifically the introduction of a definition, characterization, and a thorough typology of the fourth generation of human rights. In particular, the historical-legal method was used in the analysis of the scholarly works on the theory of the division of human rights into generations. Systemic, normative, and formal methods facilitated the examination of the legal content, namely international legislative and judicial acts concerning the rights which have emerged between the XX and XXI centuries. The comparative-legal method allowed to confront legal and factual perceptions of those rights in different countries. The method of forecasting was used to determine the possibility of the future expansion of the catalog. The methods of generalization and synthesis were used to form the complete list of human rights exhibiting the characteristics of the fourth generation.

The study of issues was conducted in three stages, namely reviewing previous work concerning the fourth generation of human rights, exploration of the current legal action towards said rights, and composition of authors typology. At the first stage, we have carried out theoretical analysis and comparison of existing methodological approaches with a goal to understand the customary classification of human rights into four generations presented in the Ukrainian and foreign legal scientific literature.

The scientific discussion on the emergence of the fourth generation of human rights exists for many years. Legal researchers debate whether those rights are a derivative of existing types or a completely new formation, which rights to include in the comprehensive catalog and based on which characteristics. However, it is too early to talk about reaching a shared opinion among explorers and developing an accepted position on many of the following issues under discussion.

One of such debatable issues is the definition of human rights included to the fourth generation, which differs exceedingly among the scientists. 
For example, M.A. Lavrik (2005) argues that the rights of the fourth generation are limited by the so-called somatic, or biological, human rights, including the right to die, the human right to dispose of organs and tissues of the body and their transplantation, sexual human rights, reproductive rights (artificial fertilization, the right to abortion, the right to sterilization, the right to contraception), the right to change sex.

A.B. Vengerov (2000) defines the rights of the fourth generation as the rights of humanity in general and includes the following rights: the right to peace, environmental, information rights, the right to nuclear safety, space.

M.P. Avdeenkova and Y.A. Dmitriev (2005) define the right of the fourth generation as the right to physical freedom.

Alternatively, G.B. Romanovsky (2009) believes that the core right that should determine the vector of development of the fourth generation of human rights should be the right to die in its various manifestations (suicide, euthanasia, etc.).

According to A.N. Golovistikova and L.Y. Grudtsyna (2008), the fourth generation of human rights should exclusively include information rights and technologies.

A. Cornescu (2009) proposes the possibility of referring to the fourth generation of rights as of the rights of future generations, ones that can not belong to an individual nor a social group. He suggests a list of rights that belong to humanity as a whole, for example, rights deriving from exploration and exploitation of cosmic space.

Whereas F. Pocar (2015) criticizes the concept of the division of human rights into three generations and emphasizes that it is necessary to add a fourth generation of human rights, which includes rights related to information technology.

V. Vitiv (2016) concludes that the fourth generation of rights contains a new paradigm of freedom of information: the development and distribution of information technology, the emergence of a global information space, the transition to the new forms of a socioeconomic system; those rights cause changes in political processes (emergence of states with information society) and sets up a need to ensure the independence of actions and the choice of lawful conduct of a person based on equal access to information, protection from incomplete or fake data and protection from the dissemination of personal information about the person.

For his part, P. Sukhorolsky (2013) disagrees with the views of other scholars on the need to distinguish the fourth generation of human rights as solely new information rights. According to the scientist, information rights cover human rights belonging to all three generations. A fundamental innovation that could lead to a new generation of rights (digital rights, Internet rights) could be considered as a separation of certain aspects of the information society in a completely new space, to which the jurisdiction of states and the effect of existing legal acts would not extend.

At the second stage, we have conducted a thorough analysis of the acceptance of the human rights of the fourth generation at the international legal level. We believe that refocusing legal scholars' attention from solely doctrinal research to the overview of international law is necessary for achieving the goal of creating a scrupulous catalog. Representatives of international cooperation make a significant contribution to the formation and development 
of said rights by ratifying global acts, conventions, declarations, and the practice of international courts.

In particular, significant progress has been made in regulating the fourth generation of human rights within the work of the United Nations Organization. Over the past few decades, they have adopted numerous regulations such as the Convention for the Protection of Human Rights and Dignity of the Human Being with regard to the Application of Biology and Medicine of 1997 and four Additional Protocols to it (including Protocol on the Prohibition of Cloning Human Beings of 1998, Protocol on Transplantation of Human Organs and Tissues of 2002, Protocol on Biomedical Research of 2005), International Declaration of Human Genetic Data of 2003, Universal Declaration of Bioethics and Human Rights of 2005, Universal Declaration of the Human Genome and Human Rights of 1997, UNO Declaration on Human Cloning of 2005.

Considering the predominance of declarative rules of conduct in this area of legal relations over those legally binding, judges of the European Court of Human Rights make an invaluable contribution to the development of the general concept of understanding human rights of the fourth generation. Their work includes dozens of cases related to various types of human rights, which scientists incorporate in the fourth generation. Among the most famous of these are the following cases: Laskey, B. France; Diane Pretty v. the United Kingdom; Evans v. the United Kingdom; Vallianatos and Others v. Greece (European Court of Human Rights, 1992, 1997, 2002, 2006, 2013).

A significant amount of judicial consolidation of the human rights of the fourth generation is performed by the European Union`s legislature. In particular, its Parliamentary Assembly and the Council have adopted more than fifty recommendations on stem cells, human genome protection, biotechnology, and intellectual property, medical data protection, human organ trafficking, xenotransplantation, the establishment of umbilical cord blood banks, and more (Council of Europe, 2014).

On the other hand, the development of a shared international legal understanding of human rights of the fourth generation is significantly hindered by their unequal national perception, both legal and factual. In particular, homosexual relationships are considered natural for many countries in Western and Northern Europe, Canada, the United States, and Australia. However, Iran, Yemen, Saudi Arabia, Sudan, Nigeria, Somalia, Iraq, and Syria implement a death penalty for participating in such relationships. The right to euthanasia is legally recognized in Belgium, Luxembourg, the Netherlands alongside several US states, but in England, Bosnia and Herzegovina, Iran, France, the Russian Federation, and other countries, including Ukraine, euthanasia is prohibited. The right to free access to the Internet is guaranteed to all citizens without any restrictions in the majority of the world. However, in countries such as Belarus, India, Egypt, China, Myanmar (Burma), North Korea, Saudi Arabia, Syria, and Turkey, access to this right is strictly controlled by the state and, in some cases, is prohibited under criminal penalty.

At the third stage, the results of the generalization of doctrinal approaches to the categorization of different types of rights that emerged at the turn of the XX and XXI centuries and the analysis of he most famous among them modern international law-making activity were reconciled and used to develop the authors' approach to their formalization. 
Based on the results of a systematic analysis of scientific and scholarly literature, international legal and national human rights acts, as well as the case law of the European Court of Human Rights, we concluded that legal doctrine does not provide a single approach to understanding the fourth generation of human rights.

By the authors' view, scholars from different countries generally interpret the fourth generation of human rights as too narrow. According to common understanding, it consists of specific individual human rights, such as the right to protection from stress, the right to die, to access the Internet, sexual rights, the right to change sex, etc. Although the attempts to substantiate an expanded interpretation are common, their authors, listing several different types, consider their catalog of fourth-generation human rights an exhaustive list and do not suggest the possibility of further evolution and differentiation. Usually, those scholars suggest including environmental rights, somatic rights, the right to nuclear safety, and space rights to the human rights of the fourth generation based on criteria of becoming prominent between the XX and XXI centuries.

We allege that available lists of the human rights of the fourth generation should be considered inconclusive because of the current formation of the latter. Authors of existing catalogs can not claim to have acquired its final form. Therefore, until the representatives of the international community develop a unified approach to understanding the fourth generation of human rights and normatively define that perspective in a convenient international legal form, we suggest describing the list of the human rights of the fourth generation as incomplete.

\section{RESULTS AND DISCUSSION}

From our standpoint, the diversity of doctrinal approaches to understanding the fourth generation of human rights indicates their relevance at the present stage of human development. Simultaneously, the narrow interpretation of the fourth generation of human rights by identifying them with only one type of human rights is disputable. After all, the fourth generation of human rights is still at the stage of its formation and therefore has not yet acquired its final form. We believe that an exhaustive list of the human rights included in the fourth generation needs to be based on its definition by the governments through generally accepted forms of international law. We consider the human rights of the fourth generation as the ones that emerged in the fields of digital technology law and somatic rights to layout the initial formation of a catalog. Let us dwell on their characteristics in more detail.

Human rights connected to digital technologies are intended to ensure free access to the use, creation, and publication of digital works, as well as access to the use of electronic devices and communication networks, including the Internet. The most famous among them are the right to access the electronic network, the right to use virtual reality, the right to communicate freely and express opinions on the Internet, the right to privacy of personal data. We emphasize that the implementation of human rights in the field of digital technologies (sometimes called «digital rights») requires additional efforts from states to address various issues. 
One of the issues is the need to guarantee the right to free access to the Internet and the equal fulfilment of arising opportunities. By way of illustration, according to the International Agency «We are social» as of 2018, only 58\% of Ukrainians used the Internet. Such a low percentage of users creates a kind of digital discrimination. After all, while some citizens receive a range of opportunities in the field of digital technologies, in particular, ordering and using e-tickets, getting seats in online queues, supporting petitions, etc., other citizens are entirely deprived of this opportunity. Thus, the introduction of the right of free access to the Internet requires predicaments to ensure the same level of access to the network for all people (in Norway, 97\% of citizens have access to the network) [9]. Other serious problems emerging with the introduction of this spectrum of rights are the lack of a reliable way to protect and keep private data secret and the total digitization of all spheres of public life, which increases the risk of cyberattacks and invasions of privacy.

Besides, the conversion of information into digital format threatens the establishment of a digital dictatorship by the state and total control over the data of citizens and their personal lives. In particular, in China, the state monitors any movement of a person, his actions on the Internet, participation in commodity-money relations, as the chief means of payment is the official electronic currency of the state. Additionally, when talking about digital rights, we cannot ignore the imperfections of technology and the constant danger of losing information due to viruses, bugs, breaks in the operation of technology, and other unforeseen circumstances that can lead to loss of personal data and other undesirable consequences. The spectrum of digital rights includes rights, the existence of which is morally problematic. There is a threat that the introduction of the right to life in virtual reality will create an opportunity for a person to stop living in the material world, which is contrary to the basic moral norms of society and the guiding principles on which law is based. The peculiarities of rights related to digital technologies include the fact that access to them may be limited. Concurrently, the state and digital service providers (for example, a provider) can limit it.

The second group of rights, which constitute the human rights of the fourth generation, are the so-called «somatic rights». They most often mean the freedom of a person to dispose of his or her own body. A list of such rights unequivocally recognized by the representatives of legal doctrine is still in development. However, the generalization of scholars' views on the types of rights belonging to the group of somatic human rights makes it possible to identify the following most frequently mentioned rights: the right to change sex; the right to organ transplantation; the right to clone; the right to artificial insemination; the right to surrogacy; the right to genetic modification; the right to euthanasia; the right to have an abortion. We must note that, in contrast to digital rights, somatic rights are actively addressed during both academic and political discussions. Their implementation is problematic because most of these rights oppose the norms of morality and religion, and society is unable to predict how their introduction will affect future generations and their development. Controversy over the introduction of somatic rights also arises in the international arena, when some states support the practice of introducing certain rights, while others openly condemn them. For example, in the UK surrogacy is permitted, while in France the introduction of such a right would be contrary to the law on adoption and inalienability of the human body. 
One of the types of somatic rights, which has been the subject of public and scientific debate for a long time, is the human right to die. Although the human right to life is enshrined constitutionally, which logically implies that a person has the opportunity to refuse to exercise this right, including having the right to terminate life - the right to die, death, as a phenomenon inevitable for any biological species, does not require legal protection, and the consolidation of such a right would conflict with the provisions that human life is the greatest social value of the state. Outside the legal sphere, this right is condemned from the standpoint of morality and religion. From the point of view of religion, God gives human life to man, and therefore only God has the right to take it away. Thus, to deprive oneself of life means to encroach on the authority of God. The legislative enshrinement of the right to die under certain conditions, namely the right to active and passive euthanasia, deserves special attention. Euthanasia is the practice of terminating the life of a person suffering from an incurable disease. The issue of the legalization of euthanasia is more ambiguous than the right to an ordinary death. The basis of euthanasia is the fact of human suffering. On the one hand, human life is the highest social value, and it must be protected from its beginning until the onset of biological death. On the other hand, when a person realizes the inevitability of death from disease, and every moment of his life he suffers from unbearable physical pain, deprivation of his right to a dignified death is a direct encroachment on the inalienable right to honor and dignity. In addition to the above-mentioned controversies that arise over the exercise of this right, there are many controversial issues related to medical ethics. In particular, the doctor who took the Hippocratic Oath turns into a murderer, because he is forced to take a person's life, even at his will, instead of saving him (Nikolsky and Panishchev, 2011).

Similar problems apply to other newly created somatic rights. Thus, the group of rights related to the practical application of reproductive technologies, including surrogacy, cloning, artificial insemination, causes significant contradictions.

Surrogacy is a method of reproduction in which a biological mother's egg, fertilized by the biological father's sperm, is transplanted into the uterus of another woman, who carries the baby throughout the pregnancy and then gives birth. In the case of the procedure of establishing parentage, the rights of the biological father will prevail over the rights of the genetic mother if there was a use of reproductive technologies. The main argument in favor of legalizing surrogacy is to create opportunities for infertile couples, or couples with genetic defects in the reproductive system, to have a child and thus obtain an opportunity to exercise their natural right of parenthood. Confirmation of the relevance of the introduction of this right is the information of the World Health Organization for 2018, according to which $5 \%$ of the human population can not have a child for immunological, genetic, anatomical, and other reasons. From a negative side, the legalization of surrogacy can lead to a change in the value spectrum of society, with its deviation towards immorality, cynicism, and mercantilism. After all, the birth certificate of a child will actually turn into an employment agreement. There are precedents of a surrogate mother refusing to give the children she bore to the biological parents. Since two embryos took root in the body at once, she demanded that her parents double the payment (Marco, 2016). 
A more controversial right related to reproductive technology is the right to have an abortion. Abortion means any artificial termination of pregnancy. The World Health Organization estimates that approximately 55 million abortions are performed worldwide each year, killing at least 55 million people growing. If we consider the problem from this point of view, abortion is one of the most dangerous phenomena for society. When parents kill their seven-year-old child, in the eyes of both public morality and law, they become immoral, unscrupulous murderers. In fact, under the conditions of abortion, the situation is identical. The church also openly condemns abortions. In this regard, the Declaration on Euthanasia, issued on behalf of the Roman Catholic Church, states that nothing can justify the killing of a human being, be it an embryo, a fetus, an incurable person. The main argument in favor of legalizing abortion is a woman's exclusive right to dispose of her own body and life. Neither the state nor the church nor the society has the right to interfere in this process because the woman will be responsible for the newborn child, and she will have to take care of it. According to S. G. Stetsenko, society creates significant psychological pressure on women, replacing the concepts of an embryo and a child too radically, because the embryo is both not legally and physiologically human, but the woman who bears it is a full-fledged person who may suffer from bearing and giving birth (Stetsenko, 2002).

The human right to clone is perceived to be the most ambiguous of all fourth-generation reproductive rights. Cloning is a process of asexual formation and cultivation of a new sex separating being by repeating the genetic code of an existing creature. In contrast to the rights above, human cloning is prohibited internationally, and no country in the world recognizes this process as legal. At this point in human development, society is unprepared for such a process, both morally and technically. The following range of nuances determines the danger of introducing the cloning process:

1. The cloning process is a violation of the legal principle of human dignity. The value of human life becomes equated to biological material;

2. Everyone has the right to individuality and uniqueness. A clone that is a human being is deprived of such a right;

3. The possibility of creating a large number of people can lead to the deflation of the clone's life worth, its discrimination, and consumerization (slave and dangerous labor, warfare), and the devaluation of human life in general;

4. The method of cloning is technically imperfect and its efficiency is extremely low, even in the case of its implementation on animals. Conducting such an experiment on humans is likely to lead to the appearance of defective individuals. However, only reproductive cloning is legally prohibited, while therapeutic cloning (obtaining stem cells from the embryo) is legally permitted in many countries, such as the United Kingdom. Thus, the issue of cloning requires further research both by science and by the legal regulation (Prohibit all forms of cloning, 2005).

Nowadays, the right to genetic modification of man is becoming more and more widespread. Genetic modification is an artificial replacement of the organism`s genotype with the use of genetic engineering. This branch of science is relatively new. The first operation for artificial gene replacement took place in 1993. Despite this, genetic modification is developing extremely rapidly. Genetic modification opens opportunities for the treatment of many 
diseases, such as severe combined immunodeficiency, melanoma, HIV, and others. However, despite all the advantages of this technology, it contains several nuances. This technology can be used not only to treat individuals, but also to improve or change their physical performance before or after birth. The practice of changing one's physical characteristics for the better completely destroys the principle of each person's individuality and threatens the emergence of criteria for the ideal person as a basis for discrimination.

\section{CONCLUSIONS}

In conclusion, it should be emphasized that the fourth generation of human rights is still in development, and therefore the approaches proposed by scientists to classify its rights based on existing lists can not fully reflect its actual state. In our opinion, the list of human rights of the fourth generation at the present stage of its formation includes rights related to digital technologies and somatic rights. At the same time, it is necessary to note that a doctrinal discussion of the fourth generation of human rights alone is not enough. Therefore, it is long overdue to move from the format of a scientific discussion to a fundamental, comprehensive analysis of specific human rights of the fourth generation at the international legal level, taking into account the consequences of their introduction or refusal to recognize and implement them.

Further research and practical elaboration of this issue remain relevant for the entire international community and states individually. After all, a clear understanding of the fourth generation of human rights has not been developed yet. We still need to establish the proper law-enforcement of the rights of the fourth generation on the levels of universal, international, bilateral, and regional relations.

This article emphasizes the need to intensify the international discussion on the development of representatives of different states and peoples of a global concept of human rights of the fourth generation and the transition to coordinated implementation of its provisions to the national level.

This article can be useful for the scholars of the human rights of the fourth generation, professors giving lectures on human rights, students of the legal theory, employees, or advisers of governments and international organizations.

\section{REFERENCES}

Avdeenkova, M. P., Dmitriev, Y. A. (2005). The right to physical freedom. State and law, 3, 13-22.

Case of B. v. France. Application №13343/87 of the European Court of Human Rights. (2020) Retrieved from http://hudoc.echr.coe.int/rus?i=001-57770.

Case of Diane Pretty v. the United Kingdom, Application №2346/02 of the European Court of Human Rights. (2002). Retrieved from https://hudoc.echr.coe.int/rus\#\{\%22itemid\%22:[\%22001-60448\%22]\}

Case of Evans v. the United Kingdom, Application №6339/05 of the European Court of Human Rights. (2006). Retrieved from https://hudoc.echr.coe.int/s\#\{\%22languageisocode\%22:[\%22ENG\%22],\% 22appno\%22:[\%226339/05\%22],\%22documentcollectionid2\%22:[\%22CHAMBER\%22],\%22item id\%22:[\%22001-72684\%22]\} 
Case of Laskey and others v. the United Kingdom Application №21627/93; 21628/93 of

the European Court of Human Rights (1997). Retrieved from https://hudoc.echr.coe.int/ rus\#\{\%22itemid\%22:[\%22001-58021\%22]\}.

Case of Vallianatos and Others v. Greece, Application №29381/09 and 32684/09 of the European Court of Human Rights. (2013). Retrieved from http://hudoc.echr.coe.int/rus?i=001-57770.

Cornescu, A. V. (2009). The Generations of Human's Rights. Days of Law: the Conference Proceedings. Brno: Masaryk University, 1-7.

Declaration of the United Nations Conference on the Human Environment (Stockholm Declaration). (1972). Retrieved from https://legal.un.org/avl/ha/dunche/dunche.html

Declaration on the Right to Development. (1986). Retrieved from https://www.ohchr.org/en/

professionalinterest/pages/righttodevelopment.aspx

Golovistikova, A. N., Grudtsyna, L. Y. (2008). Human rights: a textbook. Moscow: Exmo, 448.

International Covenant on Civil and Political Rights. (1966a). Retrieved from https://www.ohchr.org/en/ professionalinterest/pages/ccpraspx

International Covenant on Economic, Social and Cultural Rights. (1966b). Retrieved from https://www. ohchr.org/en/professionalinterest/pages/cescr.aspx

Internet world stats. (2018). Retrieved from https://www.internetworldstats.com/stats.htm Lavrik, M. A. (2005). To the theory of somatic human rights. Siberian Legal Bulletin, 3, 16-26.

Marco, J. R. (2016). The right to surrogacy: problems of expanded understanding. Bulletin of the National University «Lviv Polytechnic». Collection of scientific works. Series Legal sciences, 850, 245-249.

Nikolsky, E. V., Panishchev, A. L. (2011). Euthanasia as a phenomenon of anthropological catastrophe.

Business in law. Economics and Law Journal, 11, 193-197.

Pocar, F. (2015). Some Thoughts on the Universal Declaration of Human Rights and the «Generations» of Human Rights. International Human Rights Review, 10, 43-53.

Prohibit all forms of cloning. (2005). Lviv newspaper, № 52 (618), 3.

Rio Declaration on Environment and Development. (1992). Retrieved from https://www.un.org/en/ development/desa/population/migration/generalassembly/docs/globalcompact/A_CONF.151_26_Vol.I_ Declaration.pdf

Romanovsky, G. B. (2009). On the issue of the right to die as a legal basis for the legalization of euthanasia and suicide. Medical law of Ukraine: problems of management and financing of health care: Proceedings of the III All-Ukrainian scientific-practical conference on medical law (II International scientific-practical conference on international law) «Medical law of Ukraine: problems of management and financing of health care», 23-24 April, 2009 (pp. 232-234). Lviv, LOBF «Medicine and Law».

Stetsenko, S. G. (2002). Artificial abortion in the context of human rights protection. Lawyer, 5, 35-36.

Sukhorolsky, P. M. (2013). Problems of ensuring and developing human rights in the information society. Ukrainian Journal of International Law, 1, 18-23.

Texts of the Council of Europe on bioethical matters. Vol. II. (2014). Retrieved from https://www. coe.int/t/dg3/healthbioethic/Texts_and_documents/INF_2014_5_vol_II_textes_\%20CoE_\%20 bio\%C3\%A9thique_E\%20(2).pdf

Vengerov, A. B. (2000). Theory of State and Law: A Textbook for Law Schools. 3rd ed. Moscow: Jurisprudence, 528.

Vitiv, V. (2016). Informational rights as a component of the fourth generation of human rights. Scientific notes of the Institute of Legislation of the Verkhovna Rada of Ukraine. Law: Constitutional and municipal law, 6, 22-26. 